\title{
The opioid crisis and British prisons
}

Poole, Rob; Bailey, John; Robinson, Catherine A.

\section{Criminal Behaviour and Mental Health}

DOI:

$10.1002 / \mathrm{cbm} .2136$

Published: 01/02/2020

Peer reviewed version

Cyswllt i'r cyhoeddiad / Link to publication

Dyfyniad o'r fersiwn a gyhoeddwyd / Citation for published version (APA):

Poole, R., Bailey, J., \& Robinson, C. A. (2020). The opioid crisis and British prisons. Criminal Behaviour and Mental Health, 30(1), 1-5. https://doi.org/10.1002/cbm.2136

\footnotetext{
Hawliau Cyffredinol / General rights

Copyright and moral rights for the publications made accessible in the public portal are retained by the authors and/or other copyright owners and it is a condition of accessing publications that users recognise and abide by the legal requirements associated with these rights.

- Users may download and print one copy of any publication from the public portal for the purpose of private study or research.

- You may not further distribute the material or use it for any profit-making activity or commercial gain

- You may freely distribute the URL identifying the publication in the public portal ?
}

Take down policy

If you believe that this document breaches copyright please contact us providing details, and we will remove access to the work immediately and investigate your claim. 


\title{
Editorial:
}

The opioid crisis and British prisons

\author{
Rob Poole FRCPsych \\ Professor of Social Psychiatry and Co-Director \\ Centre for Mental Health and Society \\ Bangor University \\ Wrexham Technology Park \\ Croesnewydd Road, \\ Wrexham \\ Wales LL13 7YP \\ rob.poole@wales.nhs.uk
}

\author{
John Bailey BA \\ Research Officer \\ Centre for Mental Health and Society \\ Bangor University, Wales
}

\author{
Catherine A. Robinson BA, PhD \\ Professor of Social Care Research and Director \\ Social Care and Society \\ School of Health Sciences \\ Manchester University, England
}




\section{Conflicts of Interest}

We have no conflicts of interest with regard to this paper

\section{Acknowledgments}

We are grateful to Dr Sadia Nafees, Dr Emily Bebbington, Dr Justin Lawson, Lucy Jones and Simon Gill for their roles in helping to develop our thinking about prescribed opioids. Our ideas have benefitted from discussion with Dr Cathy Stannard and Emma Davies. We are grateful for Dr Lynne Grundy's support and encouragement.

\section{Keywords}

Opioids; prison; medicines management; pain; addiction 
There is increasing concern about safety in British prisons. Assaults, self-harm and deaths in custody are rising (Ministry of Justice, 2019). Substance misuse is a significant cause of morbidity and death, and extensive efforts are made to prevent illicit drugs entering prisons (Ministry of Justice/HM Prison \& Probation Service, 2019). There are less well-recognised, but nonetheless serious, challenges to the safety of the prison population related to prescribing practice for chronic pain in UK primary and secondary care.

\section{The "opioid crisis" in the USA and in the UK}

In the USA, a dominant narrative has emerged concerning opioid drugs. To summarise:

From the 1980s, medical attitudes to pain relief radically changed. Analgesic use was encouraged by a pharmaceutical industry that claimed that new high-potency synthetic opioids were invariably effective, provided sufficiently high doses were prescribed. 'Big Pharma' erroneously claimed that these drugs carried a low risk of dependency except amongst those with a pre-existing addiction problem. The consequence has been that millions of Americans have been led into drug addiction and death, in an epidemic that has particularly affected small town America, where drug abuse was previously uncommon. (e.g. see Quinones, 2016)

Irrespective of the US narrative, it is possible to say with some confidence that the problems associated with opioid prescribing in the UK are different. 
Opioid drug prescriptions/1000 population rose by 34\% in England between 1998 and 2016, but the aggregated strength of prescribed opioids/annum increased by $127 \%$ (when measured as oral morphine equivalent doses). Since 2016, prescriptions have stabilised or perhaps slightly reduced (Curtis et al., 2019). The long term increase has thus been substantial, but does not remotely match the scale of the problem in the USA. In America, monitoring and control of prescribing is more difficult than in the UK owing to the US freemarket healthcare system, but, nonetheless, there has been a significant decrease in opioid prescriptions from a peak in 2011 (Pezalla et al,. 2017). Unfortunately this has been paralleled by an increase in street use. By contrast, although in the UK the increased supply of opioids has bled onto the black market, this has not provoked an epidemic of street heroin addiction.

Drug misuse, including class A drugs, has not increased in England for over a decade, although numbers of deaths related to drug misuse have risen substantially (ONS, 2018). The latter may be due in part to the use of very high potency prescription opioids such as fentanyl, but in our opinion is just as likely to be due to disinvestment from harm-reduction orientated drug dependency services provided by fully trained specialists, which has long been recognised as the most effective approach in minimising mortality amongst heroin users (e.g. Langendam et al., 2001)

So, the situation in the UK with regard to prescribed opioids and street heroin addiction could be seen to be less dramatic than in the USA. Any sense of relief from this, however, overlooks the evidence that the UK is in the midst of an epidemic of iatrogenic harm due to the widespread use of long-term high-dose opioid drugs in the management of chronic pain. 
Deprived and marginalised people are especially at risk of chronic pain. Many people in prison come from this section of the population which, combined with the unusual nature of prison life, creates an ill-recognised additional stream of substance misuse, and the risk of professional collusion with it.

\section{Opioids and chronic pain}

It is generally accepted that the international change of heart about pain relief was led from the UK. Modern palliative care started in 1967 when Dame Cicely Saunders opened St Christopher's Hospice in Sydenham, South London, which went on to become a beacon site for global palliative care. From the outset, early and continuous use of opioids was a key component in a multi-faceted strategy to protect patients from dying in pain and distress (Baines, 2011).

Directly and indirectly, the palliative care movement has led to major improvements in endof-life care. As an unintended consequence, its success has encouraged the development of misconceptions about chronic non-cancer pain (CNCP) amongst the public and health professions alike, namely:

1. That CNCP can always be eliminated if sufficient doses of strong analgesic drugs are administered

2. That the use of opioids to control pain is rarely associated with problems due to tolerance, dependency or addiction 
3. That exacerbations of CNCP in patients on opioids are necessarily due to worsening of underlying, disease-driven, pain ("breakthrough pain") and that increasing opioid dose is the appropriate response

4. That side effects of opioids are trivial in comparison to therapeutic benefits

Although there are British pain clinicians who would argue that each of these is correct, there is a substantial body of opinion, and some reasonably persuasive evidence, contradicting each point:

1. Opioids are highly effective short-term analgesics, but there are few or no published trials of their long-term or high-dose use (Chou et al., 2015). There are many patients who are in pain despite such regimens, clearly demonstrating that CNCP cannot always be eliminated through drug treatment.

2. The development of tolerance to these drugs is invariable, and commences within days. The degree of tolerance varies for different effects and between individuals. Some develop tolerance to sedation at surprisingly high doses, whilst tolerance to respiratory depression is generally less marked. Very few develop significant tolerance to inhibition of gut motility, so that all opioid patients are constipated

3. Fluctuations in chronic pain do not necessarily reflect disease progress. In fact, it is the nature of CNCP that it varies hour-by-hour, day-by-day and week-by-week, due to physical and emotional variables such as activity and mood. The phenomenon of opioid-induced hyperalgesia is not fully understood, but it is probably an intrinsic component of tolerance. Its effects are usually unimportant at low doses, but they become marked as dose rises. Worsening of pain can be due to opioid-induced 
hyperalgesia (Mitra, 2008). Increases in dose lead to temporary relief, followed by further opioid-induced pain. We have labelled this the 'pain escalator', alluding to the World Health Organisation's Pain Ladder (Ballantyne et al., 2016): ladders are climbed but escalators carry you upwards. The 'pain escalator' is driven by opioidinduced hyperalgesia: patients come to believed that their underlying pain is inexorably rising and can only be controlled by ever-increasing doses of analgesics.

4. Although many patients find opioid side effects intolerable and quickly discontinue, a substantial minority of CNCP patients end up on high doses long term. The absolute number in the UK is probably large (we have submitted data for publication suggesting at least 100,000$)$. Mortality associated with these drugs is known to increase with dose. The full impact of high-dose regimens (commonly defined as $120 \mathrm{mg}$ oral morphine equivalent/day and above) is only clearly seen when patients radically reduce, or stop, the drugs over a short timescale. After initial withdrawal is over, pain is rarely worse than before and often improves. Sedation stops. There are major improvements in cognitive function (especially higher executive functions), mood and functional activity. For most, if not all, high dose regimens are not just ineffective, they are harmful.

This is no reason for therapeutic nihilism. Many clinicians working with chronic pain believe that pain management requires a predominantly psychosocial approach that aims to give patients better understanding and control over their pain. There is a role for medication, including low-dose opioids, but drugs cannot be expected to resolve chronic pain. For the time being, however, opioid medication remains the mainstay of chronic pain management in UK health care. This causes problems when patients are sent to prison. 


\section{Pain medication in the UK prison population}

All illnesses aggregate in the poorest sections of society, owing to powerful effects of social determinants of ill-health (Poole et al., 2014), and chronic pain is no exception. Those in the population most at risk of imprisonment are particularly likely to be taking prescribed opioids. In prison, these drugs are even more problematic than in the wider community. They are easily redistributed through the prison population, through sale or intimidation.

The lives of people incarcerated in prison are boring and barren. There are few distractions from chronic pain. The ability to "get out of it" temporarily through intoxication is attractive, but dangerous. Drugs such as oxycodone are extremely potent. The strongest slow release oxycodone tablet contains $120 \mathrm{mg}$ ( $240 \mathrm{mg}$ oral morphine equivalent). A very small number of tablets can kill someone who is opioid-naive or otherwise vulnerable to respiratory depression (many older men in prison have smoking-related lung disease). The problems associated with opioids are compounded by the widespread use of gabapentinoid drugs (pregabalin and gabapentin). Gabapentinoid use is rising in drug abusing populations, and they are implicated in deaths (Evoy et al., 2017)

In prisons, uncritical prescribing of medications reported to have been taken in the community is not appropriate, as this undermines the health of individuals and of the prison population in general. The introduction of assertive but careful medicines management regimens in prison carries the promise of health benefits beyond those that are currently enjoyed by the rest of the population, particularly with regard to avoidance of harms with no therapeutic value. 
Medicines management regimens of this sort do exist in some prisons and our group will shortly submit an evaluation of one for publication. They rest on prompt and careful assessment of the patient's health status on arrival in prison, which often leads to reduction and discontinuation of medications against the patient's wishes. Patients are generally regarded as customers with a host of rights, so this is controversial. However, to prescribe knowing that the drugs are causing harm could be considered to be in conflict with the medical code, and forced withdrawal of damaging and ineffective medication regimens is sometimes necessary in the wider community. Its application in prison does not intrinsically involve different standards of care for prison and general populations. On the contrary, it could be regarded as a form of equivalence of care. After all, notwithstanding online supply, if patients have a right to whatever medication they want, drugs may as well be sold over the counter without restriction.

Recently published guidance from the Royal College of General Practitioners Secure Environments Group (Royal College of General Practitioners, 2019) carefully addresses these points, but this does not prevent controversy.

\section{Resistance}

There is a small group of clinicians and researchers in the UK working on ways of rationalising long-term high-dose opioid regimens, with the objective of improving individual pain management, daily functioning and safety. Although they enjoy considerable support and encouragement from many colleagues, they have all met with marked 
institutional and professional opposition as well. Resistance has been particular strong with regard to prison medicines management.

In a rational world, UK prisons would offer structured rehabilitation activity for those detained, which would include help with chronic health problems. The availability of this at present is very poor. Prison patients who have medications reduced or stopped without their agreement often become disgruntled when they think that they face increased pain and/or boredom, or the loss of a marketable commodity. This has an impact on prison staff, who may then become unsupportive of the strategy. Some wider community medical colleagues take offence at a perceived accusation of complicity in an iatrogenic problem. In our opinion, the problem is not about careless prescribers. The real culprit is an atomised, overstretched health system that has not challenged received wisdom about pain relief until very recently (Welsh Government, 2019). Prisoners' families, faced with complaints about withdrawal of medications previously sanctioned by doctors, and already understandable concerned for their loved ones' welfare, complain of heartless and inadequate health care. Journalists are rarely prepared to construe anything about prisons or those held within them as positive, but they are very interested in allegations of neglect involving health professionals. Needless to say, those working in this field have to be robust and insist on sticking to the rationality and evidence in the face of opposition that can be personally threatening.

\section{Conclusion}

Much of the above is based upon experience of working with chronic pain and in prisons for many years, together with the limited evidence base. There is a pressing need for research 
about high-dose opioids in general, and thorough evaluation of the impact of systematic and well thought-through approaches to tackle the problem at individual and population levels. The prison population is especially vulnerable with regard to abusable drugs, and it is important we develop prison-based responses to difficulties that have their origins in the mainstream health services.

\section{References}

Ballantyne JC, Kalso E, Stannard C (2016) WHO analgesic ladder: a good concept gone astray. BMJ 2016;352:i20. doi: https://doi.org/10.1136/bmj.i20

Baines M (2011) Pioneering days of palliative care. European Journal of Palliative Care, 18, $223-227$

Chou R, Turner JA, Devine EB, Hansen RN, Sullivan SD, Blazina I, Dana T, Bougatsos C, Deyo RA (2015) The Effectiveness and Risks of Long-Term Opioid Therapy for Chronic Pain: A Systematic Review for a National Institutes of Health Pathways to Prevention Workshop, Annals of Internal Medicine,162, 276-286. DOI: 10.7326/M14-2559

Curtis HJ, Croker R, Walker AJ, Richards GC, Quinlan J, Goldacre B (2019) Opioid prescribing trends and geographical variation in England, 1998-2018: a retrospective data base study. Lancet Psychiatry, 6. 140-150. https://doi.org/10.1016/S2215-0366(18)30471-1

Evoy KE, Morrison MD, Saklad SR (2017) Abuse and Misuse of Pregabalin and Gabapentin. 
Langendam MW, van Brussel GHA MD, Coutinho RA, van Ameijden EJC (2001)

The Impact of Harm-Reduction-Based Methadone Treatment on Mortality Among Heroin Users. American Journal of Public Health. 91, 774-780

Ministry of Justice and Her Majesty's Prison and Probation Service (2019, April 3) National Prison Drugs Strategy. Retrieved from

https://www.gov.uk/government/publications/national-prison-drugs-strategy

Ministry of Justice (2019, January 31) Safety in Custody Statistics, England and Wales:

Deaths in Prison Custody to December 2018 Assaults and Self-harm to September 2018

[PDF] Retrieved from https://www.gov.uk/government/statistics/safety-in-custody-

quarterly-update-to-september-2018

Mitra S (2008) Opioid-induced hyperalgesia: Pathophysiology and clinical implications.

Journal of Opioid Management, 4, 123-130. doi: http://dx.doi.org/10.5055/jom.2008.0017.

Office of National Statistics (2018, February 7). Statistics on drug misuse: England 2018 [PDF] Retrieved from https://digital.nhs.uk/data-and-

information/publications/statistical/statistics-on-drug-misuse/2018

Pezalla EJ, Rosen D, Erensen JG, Haddox JD, Mayne TJ (2017) Secular trends in opioid prescribing in the USA, Journal of Pain Research. 10. 383-387. doi: $10.2147 / J P R . S 129553$ 
Poole R, Higgo R, Robinson C (2014) Mental Health and Poverty. Cambridge: Cambridge University Press

Quinones S (2016) Dreamland: The True Tale of America's Opiate Epidemic. New York: Bloomsbury Press

Royal College of General Practitioners (2019, January) Safer Prescribing In Prisons (second edition) [PDF] Retrieved from https://www.rcgp.org.uk/policy/rcgp-policy-areas/prison$\underline{\text { medicine.aspx }}$

Welsh Government (2019, May 3) Living with persistent pain in Wales: guidance [PDF] Retrieved from https://gov.wales/people-experiencing-persistent-pain-guidance 